\title{
Potato mop-top virus RNA Can Move Long Distance in the Absence of Coat Protein: Evidence from Resistant, Transgenic Plants
}

\author{
Kara D. McGeachy and Hugh Barker \\ Scottish Crop Research Institute, Invergowrie, Dundee, DD2 5DA, U.K. \\ Accepted 6 October 1999.
}

\begin{abstract}
Transgenic expression of a translatable version of the Potato mop-top virus (PMTV) coat protein (CP) gene (encoded by RNA 3) in Nicotiana benthamiana prevented production of symptoms and infective virus particles. RNAs 1 and 2 accumulated in inoculated and systemic leaves but, apart from small amounts of $\mathrm{CP}$ transgene RNA transcript, no genomic-length RNA 3 was found. Crude leaf extracts from inoculated plants were not infective. However, when RNA extracts from such transgenic plants were inoculated to nontransgenic $N$. benthamiana and $N$. clevelandii, RNA 1 and RNA 2 replicated in systemic leaves of both species in the absence of RNA 3 and virus particles, but symptoms did not develop. We suggest that the triple-gene block proteins of PMTV (encoded by RNA 2) represent a class of long-distance RNA movement factors.
\end{abstract}

Potato mop-top virus (PMTV) particles encapsidate three genomic, single-strand, positive-sense RNA molecules: RNA $1(6.5 \mathrm{~kb})$ encodes the replicase functions (Savenkov et al. 1999); RNA 2 (3 kb) encodes the triple-gene block proteins (thought to be involved in virus movement) and a cysteinerich protein of unknown function; and RNA 3 (2.3 kb) encodes the coat protein $(\mathrm{CP})$ along with a possible readthrough protein (thought to be involved with vector transmission) that is expressed by leaky termination of the CP gene stop codon (Scott et al. 1994; Kashiwazaki et al. 1995). Nicotiana benthamiana was transformed to express the $\mathrm{CP}$ gene of PMTV and previous studies have characterized the resistance conferred by this transgene (Reavy et al. 1995; Barker et al. 1998). Nearly all of the $T_{1}$ plants from 10 independent transgenic lines were resistant to particle or RNA inoculation, identified by failure to accumulate infectious virus particles (assessed by infectivity assay) and lack of symptoms. Barker et al. (1998) suggested that the PMTV CP transgene is unique because, although it depends on CP translation to be effective, it mediates very strong resistance in transformed lines.

Although infectious particles did not accumulate in transgenic $\mathrm{T}_{1}$ plants, attempts were made to determine if any

Corresponding author: H. Barker; Telephone: 01382562731

Fax: 01382 562426; E-mail: H.Barker@scri.sari.ac.uk genomic PMTV RNAs could be detected. Plants of $N$. benthamiana line W5 (Reavy et al. 1995) were inoculated with crude leaf extracts from PMTV-infected, wild-type (WT) plants. Polymerase chain reaction (PCR) was used in all experiments to identify nontransgenic segregants (which were discarded) and, following inoculation with PMTV isolate 174 (Reavy et al. 1997), accumulation of infectious virus particles was assessed by infectivity assay (Reavy et al. 1995). A few infected transgenic plants were detected $(<5 \%)$ but these were discarded, so only those in which infectious virus did not accumulate were tested. RNA extracts prepared from systemic and inoculated leaves were analyzed by Northern (RNA) blotting with probes specific to RNA 2 and RNA 3 (Webster and Barker 1998).

In the first experiment, groups of plants were analyzed up to 22 days post inoculation (DPI). In inoculated leaves of WT plants, RNAs 2 and 3 were first found at 3 to $6 \mathrm{DPI}$; in transgenic plants RNA 2 could be found from day three, but RNA 3 was never detected (Table 1). In systemic leaves of WT plants, RNAs 2 and 3 were present at 6 to 8 DPI but in transgenic plants RNA 2 was not detected until 22 DPI and, as in inoculated leaves, RNA 3 was not detected (Table 1). Hence-

Table 1. Detection of Potato mop-top virus (PMTV) RNA in transgenic and nontransgenic (wild-type [WT]) Nicotiana benthamiana at intervals after inoculation with infective virus ${ }^{\mathrm{a}}$

\begin{tabular}{lccc}
\hline $\begin{array}{l}\text { Plant type and } \\
\text { leaf tissue assayed }\end{array}$ & $\begin{array}{c}\text { RNA } \\
\text { species } \\
\text { assayed }\end{array}$ & $\begin{array}{c}\text { Success } \\
\text { of RNA } \\
\text { detection }\end{array}$ & $\begin{array}{c}\text { Earliest time (days) } \\
\text { RNA detected post } \\
\text { inoculation }\end{array}$ \\
\hline WT inoculated & 2 & Yes & 3 \\
WT inoculated & 3 & Yes & 6 \\
Transgenic inoculated & 2 & Yes & 3 \\
Transgenic inoculated & 3 & No & - \\
WT systemic & 2 & Yes & 6 \\
WT systemic & 3 & Yes & 8 \\
Transgenic systemic & 2 & Yes & 22 \\
Transgenic systemic & 3 & No & - \\
\hline
\end{tabular}

a Transgenic W5 plants were manually inoculated with extracts of freshly macerated leaves taken from infected WT $N$. benthamiana plants ( $1 \mathrm{~g}$ of leaf per $5 \mathrm{ml}$ of water). None of the tested plants contained infectious virus particles as determined by infectivity assays of crude leaf extracts. At each sample point $(3,6,8,10,13,17$, and 22 days post inoculation), RNA extracts were made from pooled leaf tissue of four inoculated plants and analyzed by Northern (RNA) blotting with probes specific to RNAs 2 and 3. 
forth, for the sake of simplicity, RNA extracts from plants in which Northern blot analysis detected RNA 2 but not RNA 3 are referred to as "RNA 2+/RNA 3-". Such RNA 2+ /RNA 3 - plants were symptomless.

In the second experiment, systemic leaves of individual inoculated plants were assessed at 10, 21, 31, and 43 DPI. Only two of nine transgenic plants contained RNA 2 at 21 DPI, whereas all three tested WT plants contained RNA 2 from 10 DPI. At 31 DPI, RNA 2 was present in eight of nine transgenic plants but at 43 DPI it was detected in only two, whereas all WT plants contained RNA 2 until 43 DPI. In this experiment, transgenic plants contained less RNA 2 than WT plants and it is possible that failure to detect RNA 2 in older transgenic plants may have resulted from a decline below the level of detection. RNA 3 was detected from 21 DPI in WT plants but was never found in transgenic plants.

RNA extracts were analyzed in another experiment with a cDNA probe to RNA 1 consisting of a 450-bp, digoxigeninlabeled PCR product encoding sequence in approximately the middle of an incompletely sequenced PMTV RNA 1 (B. Reavy, personal communication). Systemic tissue of transgenic plants that were RNA 2+ /RNA 3- also contained RNA 1 in amounts similar to those in PMTV-infected WT plants (data not shown), although very little RNA 1 could be detected in any plant. However, it can be assumed that when RNA 2 is detected RNA 1 must also be present because it encodes the PMTV replicase functions (Savenkov et al. 1999).

The following hypothesis can be proposed to explain some aspects of CP transgenic resistance now that it is known that RNAs 1 and 2 of PMTV can replicate independently of RNA 3. After inoculation, RNA 3 replication is inhibited but RNAs 1 and 2 replicate normally and move out of the initially infected cells to infect the rest of the leaf. Thereafter, continued inhibition of RNA 3 replication will not be a factor because RNAs 1 and 2 can replicate independently. Thus, resistance to RNA 3 replication and production of infective particles seems likely to be based on resistance expressed in the cells that encounter the initial challenge inoculum. This hypothesis is consistent with the finding that infectious virus is found in a very small proportion of transgenic plants, in which challenge inoculum must be effective in initially infected cells and is able to overcome the resistance mechanism. However, infectivity in such plants was often detected in only one of either two or three assays, and plants often did not produce symptoms (Barker et al. 1998). Transgene-mediated resistance must be effective at a later stage of infection in such plants.

Barker et al. (1998) found that, when the PMTV CP transgene was mutated to include three early termination codons to prevent CP translation, resistance was not expressed. This suggests that $\mathrm{CP}$ translation is an important part of the resistance process. If $\mathrm{CP}$ does play a vital role, it seems unlikely that it is acting to prevent uncoating of input PMTV particles in inoculated leaves because replication of particles containing RNAs 1 and 2 is not affected, and resistance is also expressed against RNA inocula (Barker et al. 1998). Transgenically expressed PMTV CP must have some other function, acting on its own or in conjunction with transcript RNA to prevent RNA 3 replication.

The possibility was considered that the systemic, longdistance movement of PMTV RNAs 1 and 2 in the absence of RNA 3 was mediated by the presence of transgenically ex- pressed CP. To test this, RNA extracts made 28 DPI from RNA 2+ /RNA 3- transgenic plants were inoculated to WT plants, from which nine of 24 were later found to RNA 2+ /RNA 3-. RNA extracts from systemic tissue of RNA 2+ /RNA 3- WT plants were inoculated to a second set of WT plants, of which 11 out of 13 were later found to be RNA 2+ /RNA 3- (Fig. 1). Infectious PMTV could not be found by infectivity assays of crude leaf extracts of RNA 2+ /RNA 3WT plants, and RNA 3 was never detected by Northern blotting. This provides evidence that subliminal amounts of RNA 3 did not survive in RNA 2+ /RNA 3- transgenic plants to cause infection when transferred to WT plants. A PMTV cul-

\section{RNA 2}

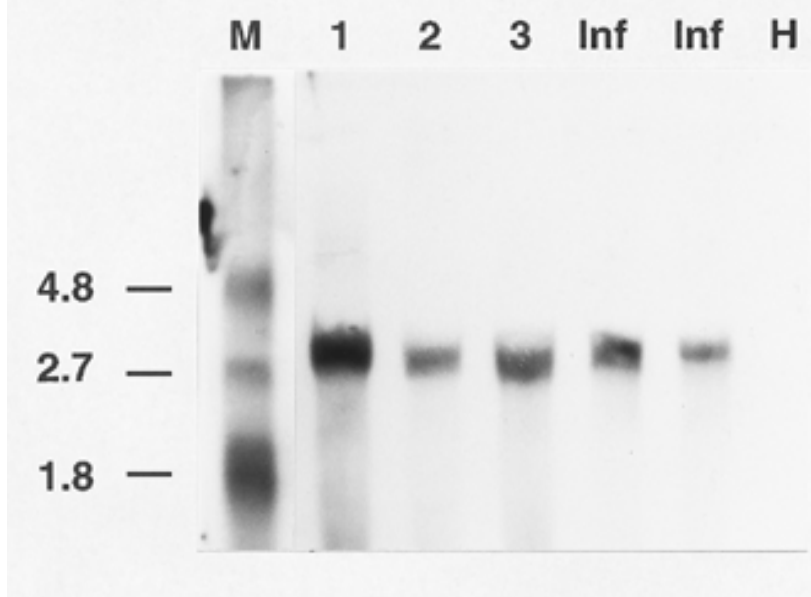

RNA 3

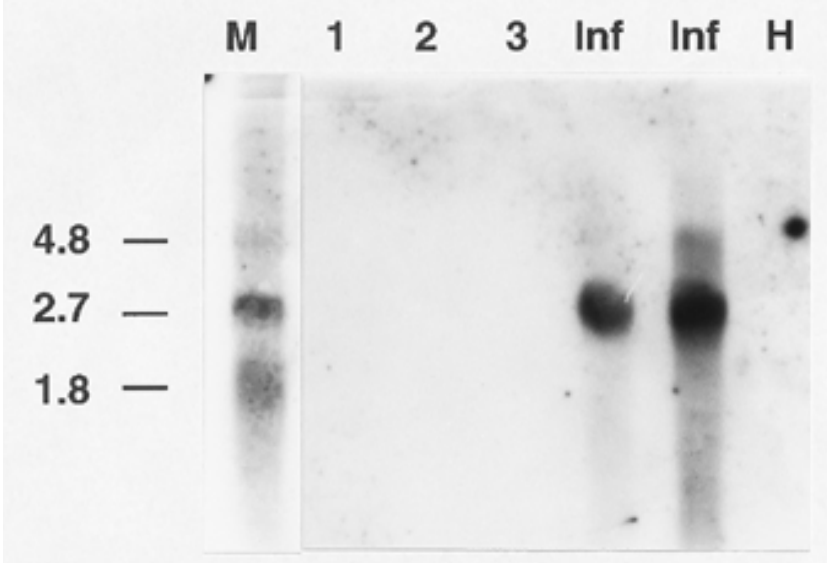

Fig. 1. Northern (RNA) blot analysis of systemic leaf RNA extracts from three wild-type (WT) Nicotiana. benthamiana plants (lanes 1-3) inoculated 22 days previously with RNA extracts from WT RNA 2+ /RNA 3plants, two infected WT $N$. benthamiana plants (lanes "Inf"), and a virus-free, healthy plant of $N$. benthamiana (lane "H"). RNA (10 $\mu \mathrm{g}$ of RNA per lane) was run on two gels and blots were treated with probes specific to RNA 2 and RNA 3. Positions of genomic-length Potato moptop virus (PMTV) RNA 2 and RNA $3\left(3 \times 10^{3}\right.$ and $2.3 \times 10^{3}$, respectively) are shown. Marker RNA is in lane "M". For transmission of infective RNA to the WT plants, total RNA extracts prepared from leaves as described by Webster and Barker (1998) were inoculated to corundum-dusted leaves at a concentration of $400 \mu \mathrm{g}$ of RNA per $\mathrm{ml}$ in the presence of 0.5 to $1 \mathrm{mg}$ of bentonite per $\mathrm{ml}$. 
ture lacking RNA 3 and virus particles was maintained by further serial passages with RNA extracts. WT plants infected with RNAs 1 and 2 showed no symptoms. Attempts were made to transmit RNAs 1 and 2 by graft inoculation. Scions from known RNA 2+ /RNA 3- plants were grafted into six virus-free WT stock plants. At $26 \mathrm{DPI}$, one stock plant was RNA 2+/RNA 3-; at 46 DPI, four plants were RNA 2+ /RNA 3-.

$N$. clevelandii were inoculated with RNA extracts from $N$. benthamiana plants that were RNA 2+ /RNA 3-. RNA extracts made 28 DPI from systemic leaves of the $N$. clevelandii were analyzed by Northern blotting (Fig 2). Of six N. clevelandii plants thus inoculated, five contained substantial

\section{RNA 2}

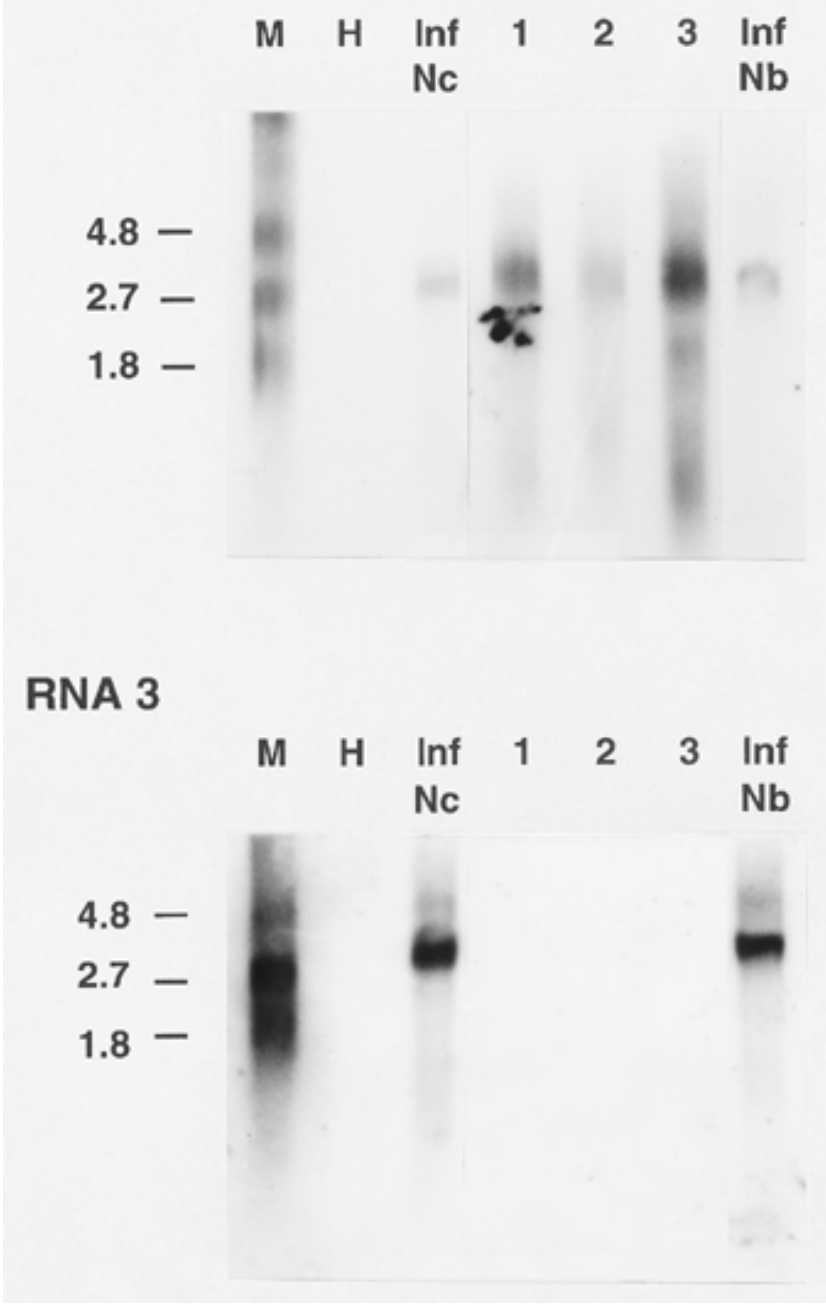

Fig. 2. Northern (RNA) blot analysis of systemic leaf RNA extracts from three Nicotiana clevelandii plants (lanes 1-3) inoculated 28 days previously with RNA extracts from a wild-type (WT) $N$. benthamiana RNA 2+ /RNA 3- plant, infected WT N. clevelandii plant (lane "Inf Nc"), infected WT $N$. benthamiana plants (lane "Inf Nb"), and a virus-free, healthy $N$. clevelandii plant (lane "H"). RNA was inoculated as described in Figure 1 caption. Marker RNA is in lane "M". RNA (10 $\mu \mathrm{g}$ of RNA from the $N$. benthaniana plants and $2.5 \mu \mathrm{g}$ from the $N$. clevelandii plants, per lane) was run on two gels and blots were treated with probes specific to RNA 2 and RNA 3. Positions of genomic-length Potato moptop virus (PMTV) RNA 2 and RNA $3\left(3 \times 10^{3}\right.$ and $2.3 \times 10^{3}$, respectively) are shown. amounts of RNA 2 but no RNA 3, and one plant was found to contain only a low level of RNA 2 after prolonged exposure. Similar results were obtained in other experiments (data not shown). None of the $N$. clevelandii plants containing RNAs 1 and 2 developed symptoms. The amount of PMTV RNAs in $N$. clevelandii plants (those containing RNAs 1 and 2 only and those with normal particle-producing infections) was substantially less than that found in similarly infected plants of $N$. benthamiana. These tests demonstrate that systemic spread of RNAs 1 and 2 does not depend upon a particular attribute of N. benthamiana.

$\mathrm{CP}$ is essential for efficient and rapid long-distance transport of most viruses. Exceptions include Barley stripe mosaic virus, in which CP was dispensable for systemic infection of barley plants (Petty and Jackson, 1990). Naturally occurring NM isolates of Tobacco rattle virus (infective isolates containing RNA 1 but not RNA 2, which encodes the CP) are able to move systemically (Cadman 1962; Harrison and Robinson 1986). A CP mutation impairing production of complete particles of Cymbidium ringspot virus did not affect its cell-to-cell movement and, although rapid, long-distance movement in non-virion form occurred in $N$. benthamiana, non-virion systemic spread did not, interestingly, occur in $N$. clevelandii (Dalmay et al. 1992). This situation contrasts with the results we report here, where non-virion spread of PMTV RNAs $1+$ 2 occurs readily in $N$. benthamiana and $N$. clevelandii. Members of the genus Umbravirus, such as Groundnut rosette virus (GRV), represent a special situation because they do not encode a CP but accumulate and spread systemically very efficiently within infected plants. Functional analysis of GRV ORF3 protein suggests that it is a trans-acting, long-distance RNA movement factor, because in chimeric TMV it can functionally replace CP that is critical for long-distance spread of TMV (Ryabov et al. 1999). Our studies suggest that PMTV is another example of a small group of viruses in which systemic movement is not dependent on CP expression or virion formation. Thus, the triple-gene block proteins of PMTV seem likely to function similarly to the triple-gene block proteins of BSMV (Petty and Jackson 1990) and the ORF3 protein of GRV (Ryabov et al. 1999) and represent a class of longdistance RNA movement factors.

\section{ACKNOWLEDGMENTS}

We thank our colleague Brian Reavy for advice on PMTV RNA sequence and design of PCR primers for cDNA probes. The Scottish Crop Research Institute is grant-aided by the Scottish Executive Rural Affairs Department.

\section{LITERATURE CITED}

Arif, M., Torrance, L., and Reavy, B. 1995. Acquisition and transmission of potato mop-top furovirus by a culture of Spongospora subterranea f. sp. subterranea derived from a single cystosorus. Ann. Appl. Biol. 126:493-503.

Barker, H., Reavy, B., McGeachy, K. D., and Dawson, S. 1998. Transformation of Nicotiana benthamiana with the potato mop-top virus coat protein gene produces a novel resistance phenotype mediated by the coat protein. Mol. Plant Microbe-Interact. 11:626-633.

Cadman, C. H. 1962. Evidence for association of tobacco rattle virus nucleic acid with a cell component. Nature 193:49-52.

Dalmay, T., Rubino, L., Burgyan, J., and Russo, M. 1992. Replication and movement of a coat protein mutant of cymbidium ringspot tombusvirus. Mol. Plant-Microbe Interact. 5:379-383. 
Harrison, B. D., and Robinson, D. J. 1986. Tobraviruses. Pages 339-369 in: The Plant Viruses. Vol. 2. The Rod-Shaped Plant Viruses. M. H. V. Van Regenmortel and H. Fraenkel-Conrat, eds. Plenum, New York.

Kashiwazaki, S., Scott, K. P., Reavy, B., and Harrison, B. D. 1995. Sequence analysis and gene organisation of potato mop-top virus RNA3: further evidence of herterogeneity in the genome organisation of furoviruses. Virology 206:701-706.

Petty, I. T. D., and Jackson, A. O. 1990. Mutational analysis of barley stripe mosaic virus RNA $\beta$. Virology 179:712-718.

Reavy, B., Arif, M., Kashiwazaki, S., Webster, K. D., and Barker, H. 1995. Immunity to potato mop-top virus in Nicotiana benthamiana plants expressing the coat protein gene is effective against fungal inoculation of the virus. Mol. Plant-Microbe Interact. 8:286-291.

Reavy, B., Sandgren, M., Barker, H., Heino, P., and Oxelfelt, P. 1997. A coat protein transgene from a Scottish isolate of potato mop-top virus mediates strong resistance against Scandinavian isolates which have similar coat protein genes. Eur. J. Plant Pathol. 103:829-834.

Ryabov, E. V., Robinson, D. J., and Taliansky, M. E. 1999. A plant virusencoded protein facilitates long-distance movement of heterologous viral RNA. Proc. Natl. Acad. Sci. USA 96:1212-1217.

Savenkov, E. I., Sandgren, M., and Valkonen, J. P. T. 1999. Complete sequence of RNA 1 and the presence of tRNA-like structures in all RNAs of Potato mop-top virus, genus Pomovirus. J. Gen. Virol. 80: 2779-2784

Scott, K. P., Kashiwazaki, S., Reavy, B., and Harrison, B. D. 1994. The nucleotide sequence of potato mop-top virus RNA 2: A novel type of genome organisation for a furovirus. J. Gen. Virol. 75:3561-3568.

Webster, K. D., and Barker, H. 1998. Detection and quantification of transcript RNA in transgenic plants using digoxigenin-labeled cDNA probes. Pages 437-445 in: Methods in Molecular Biology. Vol. 81. Plant Virology. G. D. Foster and S. C. Taylor, eds. Humana Press, Totowa, NJ. 